\title{
Genetic Features of $P$. falciparum Parasites Collected in 2012-2016 and Anti-Malaria Resistance Along China-Myanmar Border
}

\author{
Mei Li \\ National Institute of Parasitic Diseases \\ Hui Liu \\ Yunnan Institute of Parsitic Disease \\ Linhua Tang ( $\square$ ipdtlh@163.com ) \\ National Institute of Parasitic Disease \\ Henglin Yang \\ Yunnan Institure of Parasitic Disease \\ Maria Dorina Geluz Bustos \\ Office of the WHO Representative to Thailand

\section{Hong Tu} \\ National Institute of Parasitic Disease \\ Pascal Ringwald \\ Coordinator Director Office, Global Malaria Programme
}

\section{Research}

Keywords: Therapeutic Efficacy Study, Dihydroartemisinin-piperaquine (DHA-PIP), Anti-malaria resistance, China-Myanmar border, K13

Posted Date: September 28th, 2020

DOI: https://doi.org/10.21203/rs.3.rs-81492/v1

License: (우 (i) This work is licensed under a Creative Commons Attribution 4.0 International License. Read Full License 


\section{Abstract}

Backgrounds The therapeutic efficacy studies (TES) of T(DHA-PIP) for uncomplicated $P$. falciparum patients were implemented during 2012-2016 along China (Yunnan province)-Myanmar border, which verified the high efficacy of DHA-PIP. The study focusing on the genetic features of falciparum parasites and basing on in vivo parasite clearance time (PCT) were carried out to explore if they had produced potential resistance to DHA and PIP at molecular level.

Methods The genetic features were investigated based on K13 propeller genotypes, Copy numbers of genes pfPM2 and pfmdr1 and 9 microsatellite loci (Short Tandem Repeats, STR) flanking the K13 gene on chromosome 13. The PCT 50s basing on different K13 genotypes, sites, periods and copy numbers were compared.

Results In NW (North-West Yunnan province bordering with Myanmar) area, F446I prevalence was 58.96\% (79/134). No significant different PCT 50s presented among $3 \mathrm{~K} 13$ groups (Chi-Square=2.35, $\mathrm{P}=0.31, \mathrm{df}=2$ ) classified by $\mathrm{K} 13$ genotypes within NW area, but all of them were significantly shorter than that in SW (South-West Yunnan province bordering with Myanmar) area $(P=0.036, t=-2.11, d f=174)$ where isolates only showed wild K13 genotype. For the copy numbers of pfmdr1 gene, 14.63\% (18/123) and 62.5\% (10/16) parasite isolates showed double copies ( $\geq 1.6)$ in NW and SW areas separately, but for those of pfM2 gene, no parasite isolates did. Between isolates with single and double copies of pfmdr1 gene, no different PCT 50 presented. According to the mean Hevalues, the four K13 groups were arranged as ML group (Menglian County in SW), F446I group, Others (Non-F446I K13 mutation) group and W (wild K13 genotype) group from low to high. The mean Fst values between $\mathrm{ML}$ and $\mathrm{W}$ groups were significantly higher than other $2 \mathrm{~K} 13$ group-W pairs (Paired-T Test: $t=-2.659 \llbracket d f=8 \bowtie P=0.029 ; t=-4.966, d f=8 \bigotimes P=0.001$ ).

Conclusions According to our study, P. falciparum isolates in NW area and SW area are very different in genetic features. Artemisinin partial resistance, inferred from genetic marker, F446I, had independently appeared and spread in NW area during 2012-2016. With global application of ACTs, this pattern of artemisinin resistance producing was worth more attention. Fortunately, PIP-resistant feature basing on genetic analysis showed negative results in both areas. So, DHA-PIP was still recommended in antimalarial treatment along ChinaMyanmar border based on molecular data, which was agreed with the conclusion drawn from in vivo data obtained with same falciparum isolates.

Trial registration: ISRCTN, ISRCTN 11775446. Registered 13 April 2020 - Retrospectively registered, http://www.isrctn.com/ISRCTN11775446.

\section{Backgrounds}

In response to the widespread Chloroquine (CQ) resistance, the use of Artemisinin-based Combination Therapy (ACT) - the use of a potent short-acting artemisinin and a less-potent, long-acting partner drug was recommended world widely for the treatment of uncomplicated Plasmodium falciparum malaria [1-3]. One of the ACTs Dihydroartemisinin-Piperaquine (DHA-PIP), was started to be widely applied in Southeast Asia as the first-line antimalarial treatment for $P$. falciparum malaria since 2000s [1-2]. Recently, it was also applied in Africa, where $P$. falciparum malaria is hyper-endemic [4-10].

However, following the widespread resistance to $C Q$ and other antimalarial drugs, $P$. falciparum parasites produced resistance to DHAPIP too, shortly after it was widely used in Southeast Asia, initially showing prolonged parasite clearance time (PCT) and subsequently treatment failures as the partner drug also failed [11-24]. The epicenter of the resistance was Cambodia where CQ resistance first emerged [1-2, 11-20]. This resistance rapidly spread to other neighboring countries, such as Thailand, Vietnam, Lao, PDR and Myanmar, which all are part of the Greater Mekong sub-region (GMS) countries [25-28].

A few studies revealed that the decreasing efficiency of DHA-PIP in the GMS involved resistance to both DHA and PIP [11-21]. Based on the single nucleotide polymorphisms (SNPs) examination and correction analysis with genomic tools, mutant K13-propeller alleles, such as C580Y, R539T, Y493H, I543T, were verified to be correlated with the spread of resistance in west Cambodia and other GMS countries [29]. This finding alerted close attention to $\mathrm{K} 13$ mutation of $P$. falciparum parasites worldwide. Since parasites with increased pfmdr 1 copy number would significantly reduce in vitro susceptibility to artemisinin derivatives, such as artesunate [30-35], it is necessary to test the copy numbers of this gene to evaluate the potential resistance of falciparium parasites to artemisinin derivatives along ChinaMyanmar border. Furthermore, because the resistance of $P$. falciparum to the fast-acting artemtisinin component meaning longer exposure of the parasite to the long-acting partner drugs, the more chances of parasite survival [11-21], the resistance to PIP appeared too in the same place where artemisinin-resistant parasites were first reported. Genome-wide association studies revealing that 
amplification of two protease genes plasmepsin 2/3 (PfPM2/3) was associated with clinical resistance to PIP in Cambodia, established makers for resistance of parasites to PIP [36-37].

In China, since 1979, PIP had been used extensively as a replacement drug of CQ [38-39]. Also, artemisinin drugs had been deployed mostly as monotherapies prior to 2005 [38]. In 1990s, a series of in vitro microtechnique assays showed that resistance to multiply antimalarial drugs (pfmdr) was present in South-west Yunnan Province bordering with Myanmar, including both PIP and some artemisinin drugs [40-43]. After 2005, the national drug policy had changed first-line anti-malaria drugs to ACTs, such as DHA-PIP, Amodiaquine artesunate, artemisinin naphthoquine, artemisinin piperaquine. DHA-PIP was almost applied all over China [38].

In the surveillance of the efficacy and safety of anti-malarial drugs for the treatment of uncomplicated malaria, TES studies supported by WHO (World Health Organization) were implemented since 2008 [44-45]. Overall, the clinical follow-ups showed that DHA-PIP in 20072013 remained highly efficacious for treating uncomplicated $P$. falciparum in China-Myanmar border [45]. However, the molecular data were still unknown based on this in vivo data since 2012 which might be able to explore potentially spread and development of malaria resistance. So genetic features of $P$. falciparum isolates collected during 2012-2016 were studied retrospectively and reported here.

\section{Method}

\section{Study sites}

From 2012 to 2016, malaria patients were enrolled from 4 surveillance sites, Menglian county, Tengchong county, Yingjiang county, and Ruili city which are all bordering with Myanmar. Among them, Menglian county belongs to Pu'er prefecture located in South-west (SW) Yunnan province. The other 3 sites are part of Baoshan and and Dehong Prefecture respectively which are both located in North-west (NW) Yunnan province (See Fig. 1).

\section{Study population}

People who had traveled to Myanmar or settled along China-Myanmar border, infected with uncomplicated P. falciparum malaria, satisfying the inclusion and exclusion criteria, attending the study health clinic, aged between 6 months and 60 years old, except unmarried women 12-18 years old, were enrolled in the TES, treated on site with 3-day DHA-PIP and monitored weekly for 42 days. The follow-up consisted of the fixed schedule of check-up visits and corresponding clinical and laboratory examinations according to the WHO protocol [46]. All adult patients signed an informed consent form for participation. Parents or guardians gave informed consent on behalf of children. Children over 12 years of age signed an informed assent form.

\section{Treatment}

For falciparum patients were treated with DHA-PIP once daily for 3 consecutive days with a dose of $2 \mathrm{mg} / \mathrm{kg} / \mathrm{day}$ DHA and $16 \mathrm{mg} / \mathrm{kg} /$ day PIP. One tablet of DHA-PIP contained $40 \mathrm{mg}$ of DHA and $320 \mathrm{mg}$ PIP. DHA-PIP drugs were purchased from Chongqing Holley Healthpro Pharmaceutial CO.,Ltd and supplied by National Malaria Project of China.

All doses of medicine were supervised and patients were observed for $30 \mathrm{~min}$ after medicine administration for adverse reactions. The person giving treatment signed at the treatment sheet of the Case Report Form after every drug administration.

\section{Microscopic blood examination and blood collection}

Thick and thin films of blood were made on slides on D0, D1, D2, D3, D7, D14, D28, D35, D42. According to the WHO guidelines, treatment outcomes were classified on the basis of assessment of the parasitological and clinical outcome of antimalarial treatment [46]. Thus, all patients were classified as having early treatment failure, late clinical failure, late parasitological failure or an adequate clinical and parasitological response [46]. Two to three drops of blood were collected on filter paper on D0 and the day of failure.

\section{Parasite Clearance time (PCTs)}

Based on parasitemia data from D0 to D3 collected during following-up each case, PCTs for each case was calculated using WHO parasite clearance estimator WHOApplication-6-18. Data of Slope of Half-life $(\mathrm{H})$ and duration that $50 \%, 75 \%, 90 \%, 95 \%$ and $99 \%$ parasites was cleared (PCT 50, PCT 75, PCT 90, PCT 95 and PCT 99) were collected. Only the data of PCT 50 were used in comparison based on different genetic types and sites.

Page $3 / 20$ 


\section{Sequencing the K13-propeller domain}

The K13-propeller domain was amplified according to the description of Ariey, et al [38]. The high-fidelity Taq DNA polymerase (Takara 9158A) was purchased from Takara Biomedical Technology (Da Lian) Co., Ltd. The PCR products were sequenced by Map Biotech Co, Ltd (Shanghai) and the sequences were aligned with that of wild Pf37D to confirm the single nucleotide polymorphisms (SNP).

All parasite isolates with PCTs data were divided into different groups according to their K13 genotypes.

\section{Estimation of copy number pfM2 and pfmdr1}

DNA sequences of pfPM2 gene and pfmdr1 gene were amplified and detected according to the methods described by Witkowski, et al

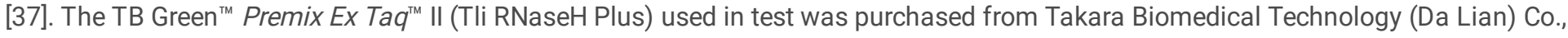
Ltd. The copy numbers of PfPM2 were estimated by the equitation of $\mathrm{Y}=0.4583 \mathrm{x}+0.7109,\left(\mathrm{x}=2^{-\Delta \mathrm{Ct}} \Delta \mathrm{Ct}=\mathrm{Ct}\right.$ PfPM2-Ct Pf $\beta$-tubulin). The copy numbers of pfmdr1 were estimated by the equitation of $\mathrm{Y}=0.4497 \mathrm{x}+0.8976, \mathrm{x}=2^{-\Delta \mathrm{Ct}} \square \Delta \mathrm{Ct}=\mathrm{Ct}$ Pfmdr1 - Ct Pf $\beta$-tubulin囚. All samples with estimated copy numbers $\geq 1.6$ were defined as containing double copies, less as single copy [37].

\section{Microsatellite loci genotyping}

Nine microsatellite loci (-56.0Kb, -50Kb, -6.36Kb, 1.7Kb, -0.15Kb, 8.6Kb, 11 Kb, 15.1 Kb, 31.5Kb) flanking the K13 gene on chromosome 13 were tested according to the method described by Talundzic, et al [1] and analyzed in Excel2016 with method of GenAlEx 6501. Genetic diversity was estimated using expected heterozygosity $(\mathrm{He})$ and coefficient of gene differentiation (Fst).

\section{Data analyses}

All the data were collected in Excel 2016. They were calculated, compared and analyzed in software GraphPad Prism 5.1 and SPSS 23. The mean values and $95 \%$ Confidence Interval $(\mathrm{Cl})$ of mean values were calculated with Column statistics method in Column analyses. Significance difference $(P<0.05$, significant; $P \geqq 0.05$, no significant)was evaluated by One-Way-ANOVA (Post-Hoc Multiple Comparisions: LSD) in SPSS 23. When the $\mathrm{P}<0.05$ in the Test of Homogeneity of Variances, Independent-Samples-T-Test would be used for further analysis. If $\mathrm{P}<0.05$ in Levene's Test for Equality of Variances presented, Nonparametric Tests ( 2 Independent-Samples-Tests, Test type: Mann-Whiteney-U) was applied instead of T-Test.

\section{Results}

\section{General briefing of samples testing}

Totally, 198 recruited volunteers were completed followed-up during 2012-2016 and 3 were lost after D7. In NW area, 8 patients (5.00\%, 8/160) showed D3 positive, while 2.44\% (1/41) in SW area (See the appendix).

K13 genotypes of 174 isolates including 169 with PCTs data and 5 without were successfully identified, in which 134 from NW area and 40 from SW area. Among the 169 isolates, copy numbers of pfM2 from 163 and pfmdr1 from 159 and STR data from 139 isolates were successfully detected and were applied in analysis.

\section{Genotypes of K13 mutations}

Among 174 parasite isolates which obtained K13 genotypes, 46.90\% (99/174) present K13 mutations (See Table 1). All 99 isolates with positive K13 mutations were collected from NW area with a total K13 mutation rate of 73.88\% (99/134) and F446I prevalence of 58.96\% (79/134). Based on comparison, prevalence of K13 mutations in different years in NW area showed dramatic increases from 2012 $(49.09 \%, 27 / 55)$ to $2013(95.74 \%, 45 / 47)$ and $2014(92.31 \%, 24 / 26)$. Most of the isolates in NW area were collected from Yingjiang county $(59.20 \%, 103 / 134)$, which showed a K13 mutation prevalence of $85.44 \%$ (88/103). Forty isolates from SW area showed K13 wild genotype. 
Table 1

Distribution of K13 genotypes in different years and different sites

\begin{tabular}{|c|c|c|c|c|c|c|c|c|c|c|}
\hline \multirow{2}{*}{$\begin{array}{l}\text { K13 } \\
\text { genotypes }\end{array}$} & \multicolumn{2}{|l|}{2012} & \multicolumn{2}{|l|}{2013} & \multicolumn{2}{|l|}{2014} & \multicolumn{2}{|l|}{2015} & \multirow{2}{*}{$\begin{array}{l}2016 \\
\text { Yingjiang }\end{array}$} & \multirow[t]{2}{*}{ Sum } \\
\hline & Yingjiang & Tengchong & Ruili & Yingjiang & Yingjiang & Menglian & Yingjiang & Tengchong & & \\
\hline C447S & 1 & 0 & 0 & 0 & 0 & 0 & 0 & 0 & 0 & 1 \\
\hline F446I & 9 & 6 & 1 & 35 & 24 & 0 & 1 & 1 & 1 & 79 \\
\hline N458Y & 1 & 1 & 0 & 0 & 0 & 0 & 0 & 0 & 0 & 2 \\
\hline P574L & 2 & 0 & 0 & 4 & 1 & 0 & 0 & 0 & 0 & 7 \\
\hline C447R & 1 & 0 & 0 & 0 & 0 & 0 & 0 & 0 & 0 & 1 \\
\hline G495C & 1 & 0 & 0 & 0 & 0 & 0 & 0 & 0 & 0 & 1 \\
\hline F483S & 1 & 0 & 0 & 0 & 0 & 0 & 0 & 0 & 0 & 1 \\
\hline A676D & 1 & 0 & 1 & 0 & 1 & 0 & 0 & 0 & 0 & 2 \\
\hline C580Y & 2 & 0 & 0 & 0 & 0 & 0 & 0 & 0 & 0 & 2 \\
\hline C469Y & 0 & 0 & 0 & 0 & 2 & 0 & 0 & 0 & 0 & 2 \\
\hline S466I & 0 & 0 & 1 & 0 & 0 & 0 & 0 & 0 & 0 & 1 \\
\hline Wild & 10 & 18 & 2 & 0 & 2 & 40 & 0 & 0 & 3 & 35 \\
\hline Total & 29 & 25 & 5 & 39 & 30 & 40 & 1 & 1 & 4 & 174 \\
\hline
\end{tabular}

The composition structure of all K13 mutations was shown in Fig. 2. A total of 11 mutation alleles were found, in which most of them were F446I $(80 \%, 79 / 99)$ and followed by P574L $(7 \%, 7 / 99)$. The other mutations alleles showed very low prevalence of $1-2 \%$, such as C469Y ( $2 \%, 2 / 99)$, C580Y $(2 \%, 2 / 99)$, N458Y $(2 \%, 2 / 99)$. Most of the mutation alleles were found in Yingjiang County. In Tengchong county and Ruili city, only $2 \mathrm{~K} 13$ mutations alleles were detected in each site (Table 1).

Based on the K13 genotypes, 129 isolates with PCTs data in NW area were divided into 3 groups. In detail, 34 isolates with K13 wild genotype were classified as W group, 75 with F446I as F446I group, 20 with other K13 mutational genotypes as Others group. Forty isolates with $\mathrm{K} 13$ wild genotype in Menglian county in SW area were defined as ML group.

\section{Comparison of PCT 50 based on K13 genotypes}

The average H, PCT50 and PCT99 in NW area were $4.96(4.46-5.46, \mathrm{~N}=129), 12.85(11.54-14.16, \mathrm{~N}=129)$ and $34.22(31.75-36.69, \mathrm{~N}=$ 129) hours, respectively. The PCT data of 4 groups are shown in Table 2. The average H value of W and F446I groups were 4.26 (3.06$5.47, \mathrm{~N}=34)$ hours and $4.51(3.87-5.14, \mathrm{~N}=71)$ hours, respectively, while those of Others and $\mathrm{ML}$ groups were a little more than 5 hours. However, all of the average PCT99 were less than 49 hours. 
Table 2

PCTs data based on K13 genotypes

\begin{tabular}{|c|c|c|c|c|c|c|c|}
\hline & & $\mathrm{H}$ & РCT50 & PCT75 & РСТ90 & РСТ95 & РСТ99 \\
\hline \multirow{3}{*}{$\begin{array}{l}\text { W Group } \\
(n=34)\end{array}$} & Mean values & 4.26 & 10.36 & 14.75 & 19.28 & 22.23 & 28.14 \\
\hline & Lower $95 \% \mathrm{Cl}$ & 3.06 & 7.69 & 11.41 & 15.41 & 18.09 & 23.59 \\
\hline & Upper 95\% Cl & 5.47 & 13.03 & 18.09 & 23.15 & 26.37 & 32.68 \\
\hline \multirow{3}{*}{$\begin{array}{l}\text { F446I Group } \\
(n=45)\end{array}$} & Mean values & 4.51 & 12.63 & 18.01 & 23.50 & 27.04 & 34.12 \\
\hline & Lower 95\% Cl & 3.87 & 10.94 & 15.84 & 20.89 & 24.17 & 30.71 \\
\hline & Upper 95\% Cl & 5.14 & 14.33 & 20.18 & 26.11 & 29.92 & 37.53 \\
\hline \multirow{3}{*}{$\begin{array}{l}\text { Others Group } \\
(n=20)\end{array}$} & Mean values & 5.72 & 13.98 & 19.66 & 25.62 & 29.57 & 37.75 \\
\hline & Lower $95 \% \mathrm{Cl}$ & 3.78 & 8.65 & 12.92 & 17.50 & 20.56 & 26.93 \\
\hline & Upper $95 \% \mathrm{Cl}$ & 7.66 & 19.31 & 26.40 & 33.74 & 38.57 & 48.58 \\
\hline \multirow{3}{*}{$\begin{array}{l}\text { ML Group } \\
(\mathrm{n}=40)\end{array}$} & Mean values & $6.23^{\star}$ & $15.41^{\star}$ & $21.38^{\star}$ & $27.42^{\star}$ & $31.29 * *$ & $38.86^{* *}$ \\
\hline & Lower 95\% Cl & 5.02 & 12.02 & 17.28 & 22.66 & 26.15 & 33.07 \\
\hline & Upper 95\% Cl & 7.44 & 18.80 & 25.49 & 32.19 & 36.43 & 44.64 \\
\hline \multicolumn{8}{|c|}{ РСТ: Parasites Clearance Time; } \\
\hline \multicolumn{8}{|c|}{${ }^{*} \mathrm{P} \leq 0.05$ when compared with the value in $\mathrm{W}$ group. } \\
\hline
\end{tabular}

The PCT 50 of different groups were compared and the results are shown in Fig. 3. The mean PCT 50 of 3 groups in NW area were 10.36 $(7.69-13.03, \mathrm{~N}=34)$ hours in $\mathrm{W}$ group, $12.63(10.94-14.3, \mathrm{~N}=75)$ hours in $\mathrm{F} 446 \mathrm{I}$ group, and $13.98(8.65-19.31, \mathrm{~N}=20)$ hours in Others group. No significant different PCT 50 presented between any two groups in this area (Chi-Square $=2.35, P=0.31, d f=2$ ). For the parasite isolates in ML group, their mean PCT 50 was 15.41 hours $(12.02-18.80, N=40)$ and significantly higher than those in $W$ group and $F 446$ I group. $(Z=-3.09, P=0.002 ; Z=-2.24, P=0.025)$.

\section{Comparison of PCT 50 based on period}

Details of K13 mutations of isolates collected in 2012 and 2013-2014 were shown in Table 3. Among parasites collected in 2012, 48.15\% (26/54) showed K13 mutations and 57.69\% (15/26) of the mutations were F446I. The total F446I prevalence were $27.78 \%$ (15/54) in 2012. For isolates in 2013 and 2014 (2013-2014 isolate), 95.65\% (66/69) of them showed K13 mutation and 86.36\% (57/66) of the mutations were F446I. The total F446I prevalence was $82.61 \%(57 / 69)$ in these 2-year period.

Table 3

K13 genotypes in different years

\begin{tabular}{|lllll|}
\hline & $\begin{array}{l}\text { Total No. of Cases with PCT50 } \\
\text { data }\end{array}$ & $\begin{array}{l}\text { No. of Cases with K13 } \\
\text { mutations }\end{array}$ & $\begin{array}{l}\text { No. of Cases with F446I } \\
\text { mutation }\end{array}$ \\
\hline 2012 & 54 & 26 & 15 & 27.78 \\
(\%)
\end{tabular}

The comparison of mean PCT 50 between isolates of $2012(11.43,9.44-13.41, \mathrm{~N}=54)$ and 2013-2014 $(13.61,11.53-15.70, \mathrm{~N}=69)$ in NW area showed no difference $(P=0.14, t=-1.49, \mathrm{df}=121)$. 


\section{Comparison of PCT 50 based on sites}

The PCT 50 of parasite isolates in NW area (12.10 hours, $10.72-13.47$ hours, $N=134)$ was significantly shorter than that in SW (ML group) area $(P=0.036, t=-2.11, d f=174)$. The mean PCT 50 of isolates in Tengchong and Yingjiang were $11.87(9.31-14.43, N=28)$ and $12.32(10.69-13.95, \mathrm{~N}=102)$ separately. However, no significant difference presented between each of these 3 surveillance sites $(F=$ $2.11, P=0.13)$. Data of those in Ruili site were not analyzed because only 6 cases were included.

\section{Amplification of pfM2 and pfmdr1 gene}

For the pfM2 gene, no multiple copies present in all isolates, though the mean copy number of isolates in NW area $(0.95,0.93-0.96, \mathrm{~N}=$ 126) was significantly lower than that in $S W$ area $(1.08,1.00-1.16, N=15)(Z=-3.36, P=0.001)$ (See Fig. 4).

The tested copy numbers of pfmdr 1 gene from 159 samples ranged from 0.97 to 2.15 . Among them, $19.35 \%$ (6/31) isolates in W group, $14.63 \%(18 / 123)$ in NW area and 62.5\% (10/16) in ML group contained multiple copies, with mean values of $1.69(1.61-1.77, N=6)$, $1.73(1.64-1.81, \mathrm{~N}=18)$ and $1.79(1.69-1.88, \mathrm{~N}=16)$ separately. The mean copy numbers of pfmdr1 gene based on $\mathrm{K} 13$ genotypes were also calculated and compared (see Fig. 5). They were $1.41(1.34-1.48, \mathrm{~N}=31)$ in W group, $1.37(1.31-1.42, \mathrm{~N}=69)$ in F446I group and $1.40(1.34-1.47, \mathrm{~N}=20)$ in Others group, with $19.35 \%(6 / 31), 13.04 \%(9 / 69)$ and $10 \%(2 / 20)$ isolates showing copy numbers of more than or equaling to 1.6 in each group. The average copy numbers were not significantly different between every two groups in NW area $(F=0.61, P=0.55, d f=2)$, but they were significant lower than that in $S W$ area $(Z=-3.21, P=0.001)$.

There was no significant difference on PCT 50 between all isolates with single and double copies of the gene $(P=0.50, t=-0.67, d f=137)$, neither between the $W$ isolates (including both of $W$ group and $M L$ group) with single and double copies of the gene $(P=0.091, t=1.73$, $\mathrm{df}=45)$.

Correlation coefficient ( $r$ value) between PCT 50 and copy numbers of pfmdr1 gene was estimated. However, no strong correlations were presented $(r=0.056, P=0.52)$.

\section{Reduced genetic He of the mutational K13 propeller allele and increased Fst between parasites of ML group and $\mathrm{W}$ group}

He values of parasite isolates were calculated basing on STR data and grouped according to different K13 genotypes and areas were shown in Fig. 6. According to their mean Hevalues, the four group were arranged as ML group, F446I group, Others group and W group from low to high. In ML group from SW area, Hevalues of parasites at all loci sites was $0(\mathrm{~N}=8)$. In NW area, average Hevalue of F446I isolates was $0.15(0.014-0.28, \mathrm{~N}=71)$ with each individual value of less than 0.30 at all loci except of one which was 0.52 and located at upstream $-56 \mathrm{~Kb}$ of $\mathrm{K} 13$ gene. The Hevalues in Others group fluctuated greatly from 0 to 0.65 with a mean value of $0.39(0.20-0.58$, $\mathrm{n}=7)$. The mean Hevalue in $\mathrm{W}$ group was the highest among 4 groups which was $0.65(0.52-0.78, \mathrm{n}=34)$. All the mean Hes showed significant difference (Chi-Square $=25.20, \mathrm{df}=3, \mathrm{P}=0.000$ ) with one another.

Fst values of parasite isolates were also calculated basing on STR data and grouped according to different K13 genotypes and areas. Nearly all Fst values at 9 different loci (See Table 4 [47]) between different groups were higher than 0.05, except of that at the site of $-56 \mathrm{~Kb}$, which presented 0.048 between Others group and W group. The mean Fst values among 4 groups at 9 different loci $(0.410 \pm$ $0.067)$ were significantly higher than that among $3 \mathrm{NW}$ groups $(0.238 \pm 0.041)$ (Paired-T Test: $t=-3.220, d f=80 \mathrm{P}=0.009)$. The highest difference between them presented at the sites of $-0.15 \mathrm{~Kb}(0.743$ and 0.143$)$ and $1.7 \mathrm{~Kb}(0.474$ and 0.213$)$ which were closest to K13 genes among 9 loci along chromosome 13. The mean Fst values between $W$ and each of other 3 groups at 9 loci were also showed in Table 4. The Fst values between ML and $W$ groups were significantly higher than other 2 pairs (Paired-T Test: $t=-2.659 \square d f=8 \square P=0.029$; $\mathrm{t}=-4.966, \mathrm{df}=8 \mathrm{PP}=0.001)$. However, Fst of F446I group and $\mathrm{W}$ group at site of $1.7 \mathrm{~kb}$ closing to $\mathrm{K} 13$ gene did not show lower value than that of $\mathrm{ML}$ group and $\mathrm{W}$ group. 
Table 4

Fst values at different loci and between different groups

\begin{tabular}{|c|c|c|c|c|c|}
\hline Loci & Among all 4 Groups & Among 3 NW Groups & $F 446 I+W$ & Others + W & $M L+W$ \\
\hline$-56.0 K b$ & 0.240 & 0.149 & 0.082 & 0.048 & 0.190 \\
\hline$-50 \mathrm{~Kb}$ & 0.237 & 0.179 & 0.170 & 0.051 & 0.189 \\
\hline$-6.36 \mathrm{~Kb}$ & 0.552 & 0.417 & 0.152 & 0.260 & 0.468 \\
\hline$-0.15 \mathrm{~Kb}$ & 0.743 & 0.143 & 0.112 & 0.112 & 0.562 \\
\hline $1.7 \mathrm{~Kb}$ & 0.474 & 0.213 & 0.304 & 0.076 & 0.258 \\
\hline $8.6 \mathrm{~Kb}$ & 0.542 & 0.432 & 0.311 & 0.198 & 0.387 \\
\hline $11 \mathrm{~Kb}$ & 0.371 & 0.274 & 0.197 & 0.104 & 0.312 \\
\hline $15.1 \mathrm{~Kb}$ & 0.087 & 0.077 & 0.057 & 0.063 & 0.063 \\
\hline $31.5 \mathrm{~Kb}$ & 0.442 & 0.256 & 0.066 & 0.184 & 0.449 \\
\hline Mean values & $0.410^{d}$ & $0.238 \mathrm{ac}$ & $0.161^{b c}$ & $0.122^{b}$ & $0.320^{a}$ \\
\hline SE & 0.067 & 0.041 & 0.032 & 0.025 & 0.053 \\
\hline \multicolumn{6}{|c|}{$\begin{array}{l}\text { a, b, c, d: No difference present if the letters on up-right of mean values are same according to paired T-Test; Significant different if } \\
\text { the letters are different. }\end{array}$} \\
\hline \multicolumn{6}{|c|}{ Differentiation Degree[40]: $0 \leqq$ Fst $<0.05$, little genetic differentiation; } \\
\hline \multicolumn{6}{|c|}{$0.05 \leqq$ Fst $<0.15$, moderate differentiation; } \\
\hline \multicolumn{6}{|c|}{$0.15 \leqq$ Fst $<0.25$, great differentiation; } \\
\hline $0.25 \leqq$ Fst, ve & yenetic differentiation & & & & \\
\hline
\end{tabular}

\section{Discussion}

Following the spreading pattern of resistance to chloroquine and sulfadoxine/pyrimethamine which first emerged in the South East Asia region in 1970s and then expanded to Africa [29, 39, 48], ACTs resistance likewise appeared in Cambodia and then spread to nearly the whole GMS [16, 25-28, 49-50].

Drug resistant parasites tend to appear among neighboring countries where different drug policies usually are applied and parasites populations at borders would experience divergent drug selection pressures [23, 27, 51-55]. Yunnan province of China is one part of the GMS. Higher malaria prevalence along the China-Myanmar border was reported than other China border areas [56], and this area was also the main source of imported malaria in Yunnan Province.

To survey the potential spread and development of malaria resistance, a few molecular studies on antimalarial drugs resistance along China-Myanmar border have been reported sequentially in recent years. All results verified an outstanding genetic feature of $P$. falciparum isolates in NW area, that F446I was the dominant K13 mutation allele, but no F446I were found in SW area [33, 57-58]. Our findings in NW falciparum isolates agreed with these findings. This state was distinctly different from some other GMS countries, such as in Cambodia and Thailand where the dominant K13 mutation was C580Y, though F446I allele was sporadically reported there. This difference might due to the parasites' accumulative adaptations to their sustained different host environments [59].

In our study, the lowest mean Hevalue $(0.15,0.014-0.28, \mathrm{~N}=71)$ was observed in $\mathrm{F} 446 \mathrm{I}$ isolates in $\mathrm{NW}$ area. This value was also lower than that of C580Y $(0.35 \pm 0.08)$ in Thailand [1]. Low He value meant low diversity within these isolates. This result indicated that F446I isolates had experienced short selection pressure or little gene exchanges with other genotypes since they appeared. Furthermore, mean Fst value of $0.161( \pm 0.032)$ at 9 microsatellite loci implied great differentiation had produced between F446I group and W group. Thus, F446l isolates were inferred to emerge newly in recent years in the process of adapting to its environmental pressures such as from antimalarial drugs and then spread along NW Yunnan-Myanmar border. 
The STR data also revealed that isolates in ML group showed low diversity within group but great genetic differentiation from other groups. This was consistent with their backgrounds that a malaria outbreak occurred there in 2014 [60] and also indicated that the genetic features of falciparum isolates in NW and SW diverged remarkably.

Recently, other independently emerging K13 mutations that showed in vitro artemisinin-resistance and having prevailed widely were reported in succession as C580Y and F446I did [1]. In 2014-2016, a new mutation (G533S) which showed significantly higher ring survival rates than the WT appeared and reached $44.1 \%$ along China-Myanmar border [61]. The Pfkelch13 R561H mutation which was confirmed of driving artemisinin was identified in 19 of 257 (7.4\%) patients at Masaka in Rwandan and phylogenetic analysis revealed they were indigenous lineage [62]. Basing on these facts, it seemed that except of spreading, new mutations could appear among falciparum isolates at the places where they received accumulative pressures from different human populations, anti-malaria medicines or even vectors. With global application of Artemisnin, this pattern of interaction between falciparum parasites and artemsinin drugs was worth more attentions.

The dominant K13 mutation, F446I had been accepted as one of artemisinin partial resistance markers which affected only ring-stage parasites [63] and widely expanded in NW area. Fortunately, no PIP-resistant isolates produced in this area inferred from the molecular analysis that only single pfM2 gene copy number present in the isolates there. These genetic features were rightly consistent with the in vivo results there that the DHA-PIP still showed high therapeutic efficacy concluded from the nearly same PCT $50 \mathrm{~s}$ between isolates of F446I and W and relatively lower D3 positive rate $(5.00 \%, 8 / 160)$ than the resistance threshold value to define ACT resistance of $10 \%$. The contrary response of unchanged efficacy of DHA-PIP to parasites between 2012 and 2013-2014 to the dramatic increase of prevalence of mutant K13 during these periods which mainly due to the spread of F446I prevalence also supported this point.

However, multiple copies of pfmdr1 gene appeared in both NW area and SW area with high prevalence of $14.63 \%$ and $62.5 \%$. Pfmdr1 gene amplification was responsible not only for the resistance to $\mathrm{MQ}$ but also for the declining susceptibility of artemisinin derivatives and had been widely reported in GMS at the beginning of 21 st century [30-35]. Out of expect, the analysis between PCT 50 s values and copy numbers of pfmdr1 gene did not present strong correction in this study. So it was suggested that the longer PCT $50 \mathrm{~s}$ of parasites in SW area might give rise by other molecular mechanism. Further research are looking forward.

According to files of using antimalarial drugs and research reports in Yunnan, MQ had never been deployed in NW area and neither in vivo or in vitro MQ resistance had been detected in SW area before 2000[64-67]. Nevertheless, falciparum isolates collected in NW area in 2007-2009 presented reduced sensitivity to MQ in vitro assays, though no pfmdr1 amplification was detected in any of the samples at that time [67]. Did the falciparum isolates with multiple copies of pfmdr1 gene along China-Myanmar border in our study newly emerge under some unknown environment pressure or spread from other areas? More studies are certainly required to verify it.

\section{Conclusions}

According to our study, falciparum isolates in NW area and SW area are very different in genetic features. Artemisinin partial resistance, inferred from the genetic marker, F446I, had independently appeared and spread in NW area during 2012-2016. With global application of ACTs, this pattern of artemisinin resistance emerging is worth more attention. Fortunately, PIP-resistant feature based on genetic analysis showed negative results. So, DHA-PIP was still recommended in antimalarial treatment in this area based on molecular data. This view also agreed with the conclusion drawn from the in vivo data with same falciparum isolates. However, none of the genetic mechanism revealed in this study related to the significant prolonged PCTs of isolates in SW area. And the origins of MQ-resistant isolates confined by double copies of pfmdr1 gene was unconfirmed. These two problems are worth more researches.

\section{List Of Abbreviations}

TES: Therapeutic Efficacy Studies

DHA-PIP: Dihydroartemisinin-Piperaquine,

PCT: Parasite Clearance Time,

STR: Short Tandem Repeats,

NW area: North-West Yunnan province bordering with Myanmar

Page $9 / 20$ 
SW area: South -West Yunnan province bordering with Myanmar

W group: P. falciparum isolates with $\mathrm{K} 13$ wild genotype in NW area

Others group: P. falciparum isolates with Non-F446I K13 mutation

ML group: P. falciparum isolates from Menglian County in SW area

CQ: Chloroquine

ACT: Artemisinin-based Combination Therapy

GMS: Greater Mekong sub-region

SNP: Single Nucleotide Polymorphisms

WHO: World Health Organization

\section{Declarations}

\section{Competing interests}

The authors declare that they have no competing interests.

\section{Ethical approval}

According to the Helsinki Declaration, ethical approval for the study was granted by the Ethics Committee of National Institute of Parasitic Diseases, China CDC. The purpose of the study was explained and then approval was sought from patients and their caretakers. Informed written consent was obtained from patient or carers of Child patients. All results were kept confidential and were unlinked to any identifying information.

\section{Consent for publication}

All authors have read and agreed to publish this article.

\section{Availability of data and material}

The data and material in this file were available by contacting Dr Mei Li, li_mei76@163.com.

\section{Authors' contributions}

Li M, Liu H, Tang LH and Yang HL designed the study and developed the protocol. Li M processed all the samples and analyzed the data and wrote the first draft of the paper. Tu H helped to analyze the data and draw the map. Liu H, Tang LH and Maria Dorina Geluz Bustos revised the paper and ensured quality TES implementation. Pascal Ringwald supplied the latest information and technical guidance on ACT resistance and suggestions on manuscript writing. All authors read and approved the final manuscript.

\section{Acknowledgements}

This study was supported by the WHO Mekong Malaria Programme (WP/10/MVP/005837) from a Consolidated Grant from USAID-PMI to WHO; the Round 6 (CHN-607-G09-M) and 10 (CHN-011-G15-M) Global Fund grant to fight AIDS, Tuberculosis and Malaria (GFATM) in China. It was also supported by the National Science Foundation of China (No. 81673113). We thank all participants for their contribution of time and patience in the study. We also thank staff of National Institute of Parasitic Diseases (NIPD) for logistic support, and clinical and laboratory staff of Menglian, Tengchong and Yingjiang County Center for Disease Control and Prevention for their hard work. We are also grateful for the support provided by the provincial health directors and the local health staff at the four sentinel sites. The opinions and recommendations expressed in this article are those of the authors and do not necessarily reflect the official views of WHO/USAID-PMI, GFATM, NIPD and YIPD.

\section{References}


1. Talundzic E, Okoth SA, Congpuong K, Plucinski MM, Morton L, Goldman IF, Kachur PS, Wongsrichanalai C, Satimai W, Barnwell JW, Udhayakumar V. Selection and Spread of Artemisinin-Resistant Alleles in Thailand Prior to the Global Artemisinin Resistance Containment Campaign. PLOS Pathogens. 2015; 10.1371.

2. Wichai S, Prayuth S, Saowanit V, Amnat Artemisinin resistance containment project in Thailand. II: Responses to mefloquine artesunate combination therapy among falciparum malaria patients in provinces bordering Cambodia. Malar J. 2012;11: 300.

3. WHO. Guidelines for the Treatment of Malaria, 3rd edn. Geneva, 2015.

4. Davlantes E, Dimbu PR, Ferreira CM, Joao MF, Pode D, Félix J, Sanhangala E, Andrade BN, Souza SdS, Talundzic E, Udhayakumar V, Owens C, Mbounga E, Wiesner L, Halsey ES, Martins JF, Fortes F, Plucinski MM. Efficacy and safety of artemether-lumefantrine, artesunate-amodiaquine, and dihydroartemisinin-piperaquine for the treatment of uncomplicated Plasmodium falciparum malaria in three provinces in Angola, 2017. Malar J. 2018; 17: 144.

5. Grandesso F, Guindo O, Messe LW, Makarimi R, Traore A, Dama S, Maman Laminou IM, Rigal J, Smet Md, Ouwe O, Oukem-Boyer M, Doumbo OK, Djimdé A, Etard JF. Efficacy of artesunate-amodiaquine, dihydroartemisinin-piperaquine and artemetherlumefantrine for the treatment of uncomplicated Plasmodium falciparum malaria in Maradi, Niger. Malar J. 2018 ; 17: 52.

6. Akano K, Ntadom G, Agomo C, Happi CT, Folarin OA, Gbotosho GO, Mokuolu O, Finomo F, Ebenebe JC, Jiya N, Ambe J, Wammanda R, Emechebe G, Basorun OK, Wewe OA, Amoo S, Ezeigwe N, Oguche S, Fatunmbi B, Sowunm Ai. Parasite reduction ratio one day after initiation of artemisinin-based combination therapies and its relationship with parasite clearance time in acutely malarious children. Infect Dis Poverty. 2018; 7: 122.

7. Smith SJ, Kamara ARY, Sahr E, Samai M, Swaray AS, Menard D, Warsame M. Efficacy of artemisinin-based combination therapies and prevalence of molecular markers associated with artemisinin, piperaquine and sulfadoxine-pyrimethamine resistance in Sierra Leone. Acta Trop. 2018; 185: 363-370.

8. Kakolwa MA, Mahende MK, Ishengoma DS, Mandara Cl, Ngasala B, Kamugisha E, Kataraihya JB, Mandike R, Mkude S, Chacky F, Njau R, Premji Z, Lemnge MM, Warsame M, Menard D, Kabanywanyi AM. Efficacy and safety of artemisinin-based combination therapy, and molecular markers for artemisinin and piperaquine resistance in Mainland Tanzania. Malar J. 2018; 17: 369. Published online. 2018;17: 10.1186.

9. The West African Network for Clinical Trials of Antimalarial Drugs (WANECAM). Pyronaridine-artesunate or dihydroartemisininpiperaquine versus current first-line therapies for repeated treatment of uncomplicated malaria: a randomised, multicentre, openlabel, longitudinal, controlled, phase 3b/4 trial. Lancet. 2018;7:391(10128): 1378-1390.

10. Lon C, Manning JE, Vanachayangkul P, So M, Sea D, Se Y, Gosi P, Lanteri C, Chaorattanakawee S, Sriwichai S, Chann S, Kuntawunginn W, Buathong N, Nou S, Walsh DS, Tyner SD, Juliano JJ, Lin J, Spring M, Bethell D, Kaewkungwal J, Tang D, Chuor CM, Satharath P, Saunders D. Efficacy of Two versus Three-Day Regimens of Dihydroartemisinin-Piperaquine for Uncomplicated Malaria in Military Personnel in Northern Cambodia: An Open-Label Randomized Trial. PLoS One. 2014; 9(3): e93138.

11. Kheang ST, Sovannaroth S, Ek S, Chy S, Chhun P, Mao S, Nguon S, Lek DS, Menard D, Kak N. Prevalence of K13 mutation and Day-3 positive parasitaemia in artemisinin-resistant malaria endemic area of Cambodia: a cross-sectional study. Malar J. 2017 ; 16 : 372.

12. Parobek CM, Parr JB, Brazeau NF, Lon C, Chaorattanakawee S, Gosi P, Barnett EJ, Norris LD, Meshnick SR, Spring MD, Lanteri CA, Bailey JA, Saunders DL, Lin JT, Juliano JJ. Partner-Drug Resistance and Population Substructuring of Artemisinin-Resistant Plasmodium falciparum in Cambodia. Genome Biol Evol. 2017; 9(6):1673-1686.

13. Mukherjee A, Bopp S, Magistrado P, Wong W, Daniels R, Demas A, Schaffner S, Amaratunga C, Lim P, Dhorda M, Miotto O, Woodrow C, Ashley EA, Dondorp AM, White NJ, Dyann Wirth, Fairhurst R, Volkman SK. Artemisinin resistance without pfkelch13 mutations in Plasmodium falciparum isolates from Cambodia. Malar J. 2017;16:195.

14. Duru V, Witkowski B, Ménard D. Plasmodium falciparum Resistance to Artemisinin Derivatives and Piperaquine: A Major Challenge for Malaria Elimination in Cambodia. Am J Trop Med Hyg. 2016; 95(6): 1228-1238.

15. Amato R, Lim P, Miotto O, Amaratunga C, Dek D, Pearson RD, Almagro-Garcia J, Neal AT, Sreng S, Suon S, Drury E, Jyothi D, Stalker J, Kwiatkowski DP, Fairhurst RM. Genetic markers associated with dihydroartemisinin-piperaquine failure in Plasmodium falciparum malaria in Cambodia: a genotype-phenotype association study. Lancet Infect Dis. Author manuscript; available in PMC 2017 Aug 21.Published in final edited form as: Lancet Infect Dis. 2017;17(2): 164-173.

16. Amaratunga C, Lim P, Suon S, Sreng S, Sivanna Mao S, Sopha C, Sam B, Dek D, Try V, Amato R, Blessborn D, Song LJ, Tullo GS, Fay MP, Anderson JM, Tarning J, Fairhurst RM. Dihydroartemisinin-piperaquine resistance in Plasmodium falciparum malaria in Cambodia: a multisite prospective cohort study. Lancet Infect Dis. Author manuscript; available in PMC 2017 Mar 1.Published in final edited form as: Lancet Infect Dis. 2016; 16(3): 357-365.

Page $11 / 20$ 
17. Duru V, Khim N, Leang R, Kim S, Domergue A, Kloeung N, Ke S, Chy S, Eam R, Khean C, Loch K, Ken M, Lek D, Beghain J, Ariey F, Guerin PJ, Huy R, Mercereau-Puijalon O, Witkowski B, Menard D. Plasmodium falciparum dihydroartemisinin-piperaquine failures in Cambodia are associated with mutant K13 parasites presenting high survival rates in novel piperaquine in vitro assays: retrospective and prospective investigations. BMC Med. 2015; 13: 305.

18. Cox J, oley LD, Bunkea T, Sovannaroth S, Ty KS, Ngak S, Bjorge S, Ringwald P, Mellor S, Sintasath D, Meek S. Evaluation of community-based systems for the surveillance of day three-positive Plasmodium falciparum cases in Western Cambodia. Malar J. 2014;13:282.

19. Lon C, Manning JE, Vanachayangkul P, So M, Sea D, Se Y, Gosi P, Lanteri C, Chaorattanakawee S, Sriwichai S, Chann S, Kuntawunginn W, Buathong N, Nou S, Walsh DS, Tyner SD, Juliano JJ, Lin J, Spring M, Bethell D, Kaewkungwal J, Tang D, Chuor CM, Satharath P, Saunders D. Efficacy of Two versus Three-Day Regimens of Dihydroartemisinin-Piperaquine for Uncomplicated Malaria in Military Personnel in Northern Cambodia: An Open-Label Randomized Trial. PLoS One. 2014; 9(3): e93138.

20. Leang R, Barrette A, Denis Bouth DM, Menard D, Abdur R, Duong S, Efficacy of Dihydroartemisinin-Piperaquine for Treatment of Uncomplicated Plasmodium falciparum and Plasmodium vivax in Cambodia, 2008 to 2010. Pascal Ringwald Antimicrob Agents Chemother. 2013; 57(2): 818-826.

21. Chaorattanakawee S, Lon C, Jongsakul K, Gawee J, Sok S, Sundrakes S, Kong N, Thamnurak C, Soklyda Chann, Chattrakarn C, Praditpol C, Buathong N, Uthaimongko NI, Smith P, Sirisopana N, Huy R, Prom S, Fukuda MM, Bethel DI, Walsh DS, Lanter Ci, SaundersD. Ex vivo piperaquine resistance developed rapidly in Plasmodium falciparum isolates in northern Cambodia compared to Thailand. Malar J. 2016; 15: 519.

22. Phyo AP, Nkhoma S, Stepniewska K, Ashley EA, Nair S, McGready R, Moo CL, Al-Saai S, Dondorp AM, Lwin KM, Singhasivanon P, DayNPJ , White NJ, AndersonTJC , Nosten F. Emergence of artemisinin-resistant malaria on the western border of Thailand: a longitudinal study. Lancet. 2012; 379(9830): 1960-1966.

23. Song J, Socheat D, Tan B, Seila S, Xu Y, Ou F, Sokunthea S, Sophorn L, Zhou C, Deng C, Wang Q, Li G. Randomized trials of artemisinin-piperaquine, dihydroartemisinin-piperaquine phosphate and artemether-lumefantrine for the treatment of multi-drug resistant falciparum malaria in Cambodia-Thailand border area. Malar J. 2011; 10: 231.

24. Tarning J, Ashley EA, Lindegardh N, Stepniewska K, Phaiphun L, Day NPJ, McGready R, Ashton M, Nosten F, White NJ. Population Pharmacokinetics of Piperaquine after Two Different Treatment Regimens with Dihydroartemisinin-Piperaquine in Patients with Plasmodium falciparum Malaria in Thailand. Antimicrob Agents Chemother. 2008; 52(3): 1052-1061.

25. Kobasa T, Talundzic E, Sug-aram R, Boondat P, Ira F. Goldman IF, Lucchi NW, Dharmarak P, David Sintasath D, Fukuda M, Whistler T, MacArthur J, Udhayakumar V, Prempree P, Chinanonwait N. Emergence and Spread of kelch13 Mutations Associated with Artemisinin Resistance in Plasmodium falciparum Parasites in 12 Thai Provinces from 2007 to 2016. Antimicrob Agents Chemother. 2018; 62(4): e02141-17.

26. Tun KM, Mallika Imwong M, Lwin KM, Win AA, Hlaing TM, Hlaing T, Lin K, Myat P Kyaw MP, Plewes K, Faiz MA, Dhorda M, Cheah PY, Pukrittayakamee S, Ashley EA, Anderson TJC, Nair S, McDew-White M, Flegg JA, Grist EPM, Guerin P, Maude RJ, Smithuis F, Dondorp AM, Day NPJ, Nosten F, White NJ, Woodrow CJ. Spread of artemisinin-resistant Plasmodium falciparum in Myanmar: a crosssectional survey of the K13 molecular marker. Lancet Infect Dis. 2015; 15(4): 415-421.

27. Imwong M, Suwannasin K, Kunasol C, Sutawong K, Mayxay M, Rekol H, Smithuis FM, Hlaing TM, Rob KMT. The spread of artemisinin-resistant Plasmodium falciparum in the Greater Mekong subregion: a molecular epidemiology observational study. Lancet Infect Dis. 2017; 17: 491-97.

28. Thanh NV, Thuy-Nhien N, Tuyen NTK, Tong NT, Nha-Ca NT, Dong LT, Quang HH, Farrar J, Thwaites G, White NJ, Wolbers M, Hien TT. Rapid decline in the susceptibility of Plasmodium falciparum to dihydroartemisinin-piperaquine in the south of Vietnam. Malar J. 2017; 16: 27.

29. Ariey F, Witkowski B, Amaratunga C, Beghain J, Langlois AC, Khim N, Kim S, Duru V, Bouchier C, Ma L, Lim P, Leang R, Duong S, Sreng S, Suon S, Chuor CM, Bout DM, Ménard S, Rogers WO, Genton B, Fandeur T, Miotto O, Ringwald P, Bras JL, Berry A, Barale JC, Fairhurst RM, Benoit-Vical F, Mercereau-Puijalon O, Ménard D. A molecular marker of artemisinin-resistant Plasmodium falciparum Nature. 2014; 505(7481): 50-55.

30. Veiga MI, Ferreira PE, Jörnhagen L, Malmberg M, Kone A, Schmidt BA, Petzold M, Björkman A, Nosten F, Gil JP. Novel polymorphisms in Plasmodium falciparum ABC transporter genes are associated with major ACT antimalarial drug resistance. PLoS One. 2011;6(5):e20212. PMID: 21633513.

31. Chavchich M, Gerena L, Peters J, Chen N, Cheng Q, Kyle Role of pfmdr1 amplification and expression in induction of resistance to artemisinin derivatives in Plasmodium falciparum. Antimicrob Agents Chemother. 2010 Jun;54(6):2455-64.

Page $12 / 20$ 
32. Pickard AL, Wongsrichanalai C, Purfield A, Kamwendo D, Emery K, Zalewski C, Kawamoto F, Miller RS, Meshnick SR.

Resistance to antimalarials in Southeast Asia and genetic polymorphisms in pfmdr1. Antimicrob Agents Chemother. 2003 Aug;47(8):2418-23.

33. LimP, Alker AP, Khim N, Shah NK, Incardona S, Doung S, Yi P, Bouth DM, Bouchier C, Puijalon OM, Meshnick SR, Wongsrichanalai C, Fandeur T, Bras JL, Ringwald P, Ariey Pfmdr1 copy number and artemisinin derivatives combination therapy failure in falciparum malaria in Cambodia. Malar J. 2009 Jan 12;8:11.

34. PriceRN, Cassar C, Brockman A, Duraisingh M, van Vugt M, White NJ, Nosten F, Krishna The pfmdr1 gene is associated with a multidrug-resistant phenotype in Plasmodium falciparum from the western border of Thailand. Antimicrob Agents Chemother. 1999, 43(12):2943-9.

35. Sidhu ABS, Uhlemann AC, Valderramos SG, Valderramos JC, Krishna S, Fidock. Decreasing pfmdr1 Copy Number in Plasmodium falciparum Malaria Heightens Susceptibility to Mefloquine, Lumefantrine,Halofantrine, Quinine, and Artemisinin. J Infect Dis. 2006;194(4): 528-535.

36. Bopp S, Magistrado P, Wong W, Schaffner SF, Mukherjee A, Lim P, Dhorda M, Amaratunga C, Woodrow CJ, Ashley EA, White NJ, Dondorp AM, Fairhurst RM, Ariey F, Menard D, Wirth DF, Volkman SK. Plasmepsin II-III copy number accounts for bimodal piperaquine resistance among Cambodian Plasmodium falciparum. Nat Commun. 2018; 9: 1769.

37. Witkowski B, Duru V, Khim N, Ross LS, Saintpierre B, Beghain J, Chy S, Kim S, Ke S, Kloeung N, Eam R, Khean C, Ken M, Loch K, Bouillon A, Domergue A, Ma L, Bouchier C, Leang R, Huy R, Nuel G, Barale JC, Legrand E, Ringwald P, Fidock DA, Mercereau-Puijalon O, Ariey F, Ménard D. A surrogate marker of piperaquine-resistant Plasmodium falciparum malaria: a phenotype-genotype association study. Lancet Infect Dis. 2017;17(2): 174-183.

38. Yang, H.L. Review and prospect of antimalarial drug application in Yunnan Province. Journal of Practical Parasitic Dieseases. 1999; 7:174-176 (in Chinese).

39. Ye R, Hu DW, Zhang YL, Huang YF, Sun XD, Wang J, Chen XD, Zhou HN, Zhang DM, Mungthin M, Pan WQ. Distinctive origin of artemisinin resistant Plasmodium falciparum on the China-Myanmar border. Scientific Reports. 2016: 20100.

40. Yang HL, Liu DQ, Dong Y, Yang PF, Liu RJ, Zhan B, Zhang CY. Sensitivity of Plasmodium falciparum to seven antimalarial in ChinaLaos border. Journal of Practical Parasitic Dieseases. 1995;13(2): 198-200 (in Chinese).

41. Yang HL, Yang PF, Liu DQ, Liu RJ, Dong Y, Zhang CY, Cqinao DQ, He H. Sensitivity in vitro of Plasmodium falciparum to Chloroquine, Pyronaridine, Artesunate and Piperaquine in South Yunnan. Journal of Practical Parasitic Dieseases. 1992; 3:198-200 (in Chinese).

42. Yang HL, Liu DQ Huang KQ, Dong Y, Yang PF, Yang YM, Liao MZ, Zhang CY, Liu RJ. In vitro sensitivity of Plasmodium falciparum to derivatives of Artesimisin. Journal of Practical Parasitic Dieseases. 1997;15(5):198-200 (in Chinese).

43. Liu DQ, Liu RJ, Zhang CY, Cai XZ, Tang X, Yang HL, Dong Y, Yang PF. Present status of the sensitivity of Plasmodium falciparum to antimalarials in China. Journal of Practical Parasitic Dieseases. 1996;14(1):37-41 (in Chinese).

44. Liu H, Yang HL, Tang LH, Li XL, Huang F, Wang JZ, Li CF, Wang HY, Nie RH, Guo XR, Lin YX, Li M, Xu JW. Monitoring Plasmodium vivax chloroquine sensitivity along China-Myanmar border of Yunnan Province, China during 2008-2013. Malaria J. 2014;13:364.

45. Liu H, Yang HL, Tang TL, Li XL, Huang F, Wang JZ, Li CF, Wang HY, Nie RH, Guo XR, Lin YX, Li M, Wang J, Xu JW. In vivo monitoring of dihydroartemisininpiperaquine sensitivity in Plasmodium falciparum along the China-Myanmar border of Yunnan Province, China from 2007 to 2013. Malaria J. 2015;14:47.

46. WHO. Susceptibility of Plasmodium falciparum to antimalarial drugs. Report on global monitoring 1996-2004. Geneva, World Health Organization, 2005 (WHO/HTM/MAL /2005.110) (http://www.who.int/malaria/resistance).

47. Balloux F, Lugon-Moulin N. The estimation of population differentiation with microsatellite markers. Mol Ecol. 2002; 11:155-165.

48. Roper C. Intercontinental spread of pyrimethamine-resistant malaria. Science. 2004; 305:1124.

49. Bai Y, Zhang JQ, Geng JT, Xu SL, Deng S, Zeng WL, Wang ZL, Mbenda HGN, Zhang J, Li N, Wu YR, Li CY, Liu H, Ruan YH, Cao YM, Yang ZQ, Cui LW. Longitudinal surveillance of drug resistance in Plasmodium falciparum isolates from the China-Myanmar border reveals persistent circulation of multidrug resistant parasites. Int J Parasitol Drugs Drug Resist. 2018; 8(2): 320-328.

50. Philip J. Rosenthal. Artemisinin Resistance Outside of Southeast Asia. Am J Trop Med Hyg. 2018; 99(6): 1357-1359.

51. Pongvongsa T, Ha H, Thanh L, Marchand RP, Nonaka D, Tojo B, Phongmany P, Moji K, Kobayashi J. Joint malaria surveys lead towards improved cross-border cooperation between Savannakhet province, Laos and Quang Tri province, Vietnam. Malar J. 2012; 11: 262.

52. Carrara Cl, Lwin KM, Phyo AP, Ashley E, Wiladphaingern J, Sriprawat K, Rijken M, Boel M, McGready R, Proux S, Chu C, Singhasivanon P, White N, Nosten F. Malaria Burden and Artemisinin Resistance in the Mobile and Migrant Population on the Thai-Myanmar Border,

Page $13 / 20$ 
1999-2011: An Observational Study. PLoS Med. 2013; 10(3): e1001398.

53. Hao MM, Jia DD, Li Q, He YS, Yuan LL, Xu SH, Chen KX, Wu J, Shen LJ, Sun L, Zhao HB, Yang ZQ, Cui LW. In vitro Sensitivities of Plasmodium falciparum Isolates from the China-Myanmar Border to Piperaquine and Association with Polymorphisms in Candidate Genes. Antimicrob Agents Chemother. 2013; 57(4): 1723-1729.

54. Bhumiratana A, Intarapuk A, Sorosjinda-Nunthawarasilp P, Maneekan P, Koyadun S. Border Malaria Associated with Multidrug Resistance on Thailand-Myanmar and Thailand-Cambodia Borders: Transmission Dynamic, Vulnerability, and Surveillance. Biomed Res Int. 2013; 2013: 363417.

55. Xu JW, Li JJ, Guo HP, Pu SW, Li SM, Wang RH, Liu H, Wang WJ. Malaria from hyperendemicity to elimination in Hekou County on China-Vietnam border: an ecological study. Malar J. 2017; 16: 66.

56. Chen GW, Wang J, Huang XZ, Li YP, Hou ZS, Li HX, Xu SY, Wei C, Zhang ZX. Serological Detection of Malaria for People Entering China from 19 Ports of Entry Covering 8 Border Prefectures of Yunnan. Journal of Practical Parasitic Dieseases. 2010;28(1):54-58 (in Chinese).

57. Huang F, Takala-Harrison S, Jacob CG, Liu H, Sun, XD, Yang HL, Nyunt MM, Adams M, Zhou SS, Xia ZG, Ringwald P, Bustos MD, Tang LH, Plowe CV. A Single Mutation in K13 Predominates in Southern China and Is Associated With Delayed Clearance of Plasmodium falciparum Following Artemisinin Treatment. Journal Of Infectious Diseases. 2015; 212: 1629-1635.

58. Feng J, Zhou DL, Lin YX, Xiao HH, Yan H, Xia ZG. Amplification of pfmdr1, pfcrt, pvmdr1, and K13 Propeller Polymorphisms Associated with Plasmodium falciparum and Plasmodium vivax Isolates from the China-Myanmar Border. Antimicrob Agents Chemother. 2015; 59(5): 2554-2559.

59. Zhu L, Tripathi J, Rocamora FM, Miotto O, Pluijm Rvd, Voss TS, Mok S, Kwiatkowski DP, NostenF , Day NPJ, White NJ, Dondorp AM, Bozdech Z, Tracking Resistance to Artemisinin Collaboration I. The origins of malaria artemisinin resistance defined by a genetic and transcriptomic background. Nat Commun. 2018; 9: 5158.

60. Liu H, Xu JW, Yang HL, Li M, Sun CD, Yin YJ, Zheng ZL, Zhang GY, Yu AS, Yang YH, Li CH, Ai S. Investigation and control of a Plasmodium falciparum malaria outbreak in Shan Special Region II of Myanmar along the China-Myanmar Border from June to December 2014. Infectious Diseases of Poverty. 2016;5:32.

61. Zhang J, Li N, Siddiqui AS, Shiling Xu SL, Geng JT, Zhang JQ, He X, Zhao LY, Pi L, Zhang YM, Li CY, Chen X, Wu YR, Miao J, Cao YM, Cui LW, Yang ZQ. In vitro susceptibility of Plasmodium falciparum isolates from the China-Myanmar border area to artemisinins and correlation with K13 mutations. Drugs and Drug Resist. 2019(10 ) 20-

62. Uwimana A, Legrand E, Stokes BH, Ndikumana JL, Warsame MM, Umulisa N, Ngamije D, Munyaneza Mazarati TJB, Munguti K, Campagne P, Criscuolo A, Ariey F, Murindahabi M, Ringwald P, Fidock DA, Mbituyumuremyi A, Menard D. Emergence and clonal expansion of in vitro artemisinin-resistant Plasmodium falciparum kelch13 R561H mutant parasites in Rwanda. Nat Med (2020). https://doi.org/10.1038/s41591-020-1005-2.

63. WHO. Artemisinin resistance and artemisinin-based combination therapy efficacy. Geneva, World Health Organization, Aug, 2018 (WHO/HTM/MAL /2018.18) (https://www.who.int/ malaria/publications/atoz/artemisinin-resistance-august2018/en/).

64. Advisory Committee of Malaria Expert, Chinese Ministry of Health. Principle and scheme for use of antimalarial drug in China. Chin J parasite Dis Con, 2002, 15(3):1-2.

65. Advisory Committee of Malaria Expert, Chinese Ministry of Health (Trial Version). Principle and scheme for use of antimalarial drug in China. Disease Control Bureau, Ministry of health. 2007-4-24, ( MH/DCB, 2007:60). City:Beijing.

66. Advisory Committee of Malaria Expert, Chinese Ministry of Health (Revised Version). Principle and scheme for use of antimalarial drug in China. Disease Control Bureau, Ministry of health. 2009-4-24, ( MH/DCB, 2009:106). City:Beijing.

67. Wang Z, Parker D, Meng H, Wu L, Li J, Zhao Z, Zhang R, Miao M, Fan Q, Wang H, Cui L, Yang Z. In vitro sensitivity of Plasmodium falciparum from China-Myanmar border area to major ACT drugs and polymorphisms in potential target gene. PLoS One.

2012;7(5):e30927.

\section{Figures}




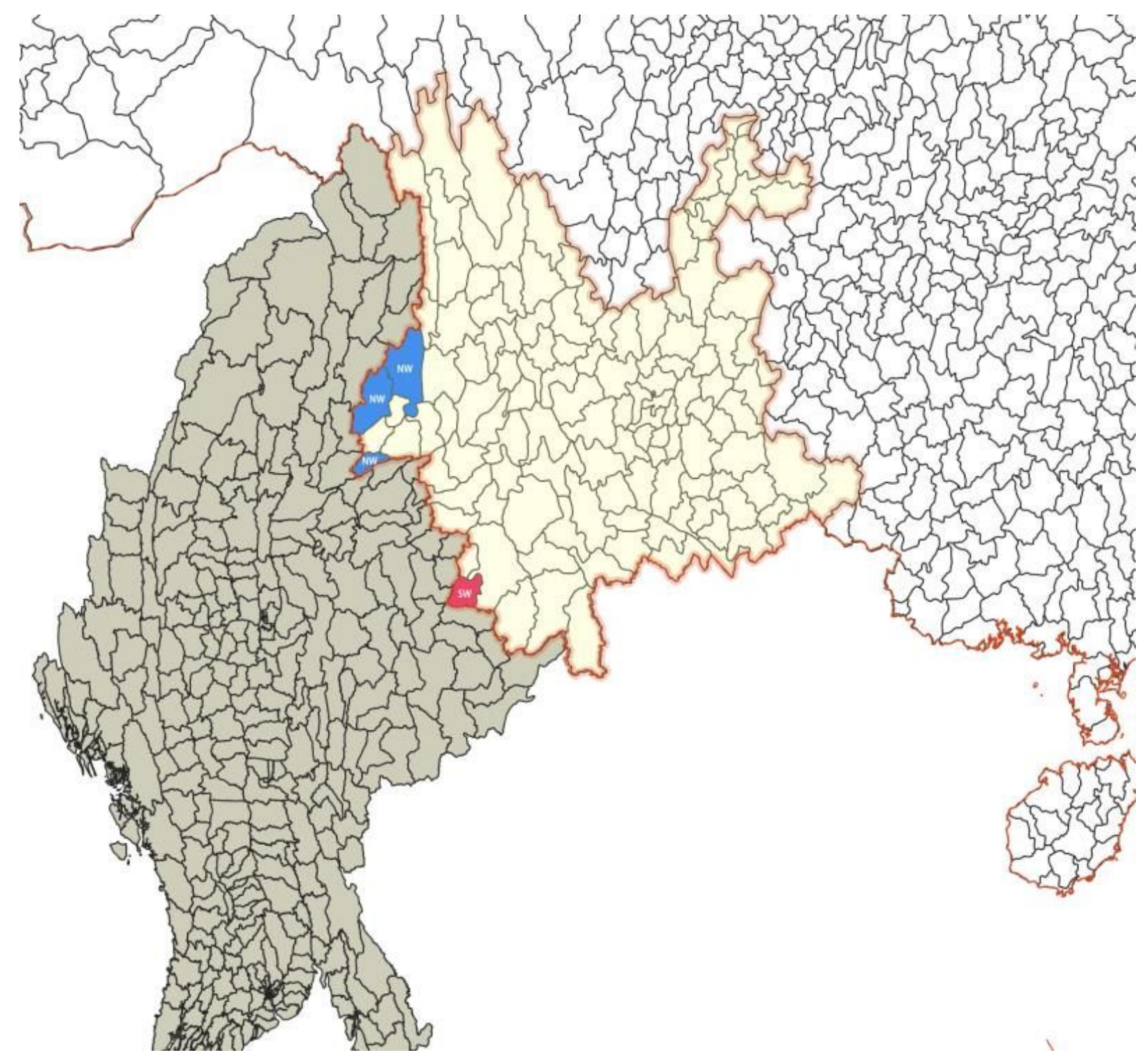

\section{Figure 1}

Study sites; Blue area: North-west Yunnan province including 3 surveillance sites; Red area: South-west Yunnan province including 1 surveillances site. Note: The designations employed and the presentation of the material on this map do not imply the expression of any opinion whatsoever on the part of Research Square concerning the legal status of any country, territory, city or area or of its authorities, or concerning the delimitation of its frontiers or boundaries. This map has been provided by the authors. 


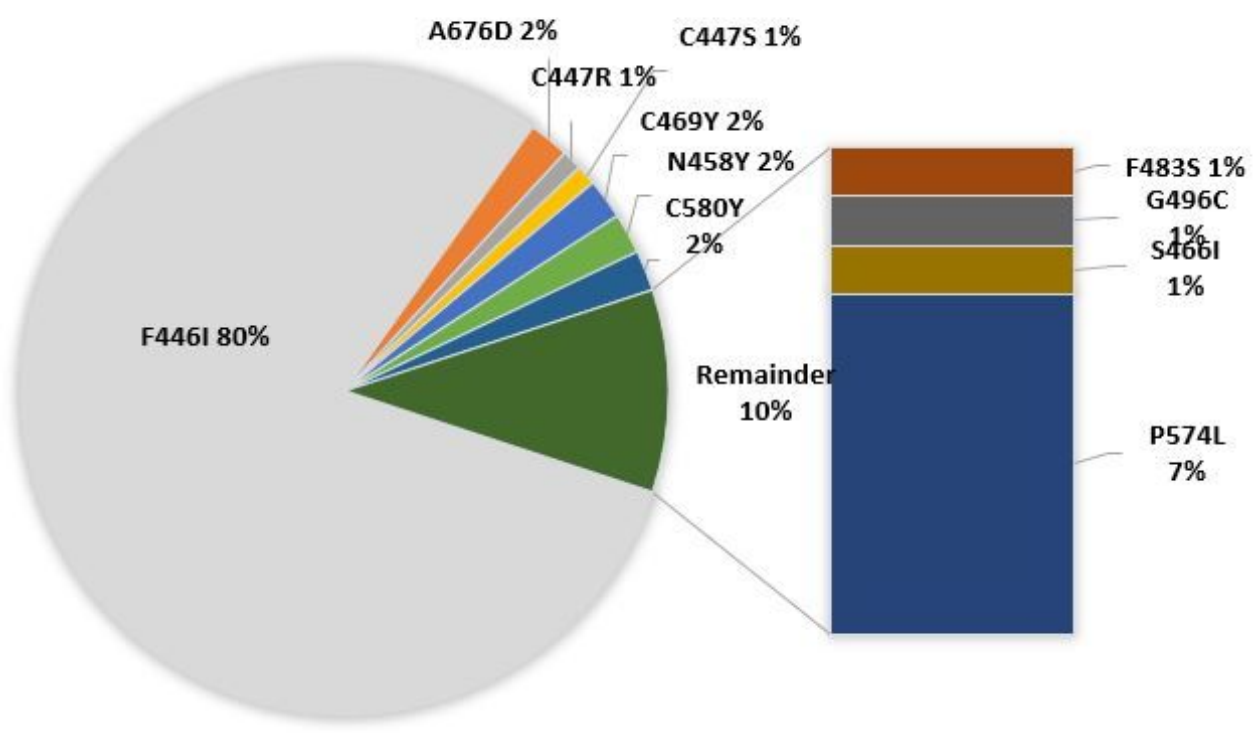

Figure 2

Composition structure of different K13 mutational genotypes along China-Myanmar border 


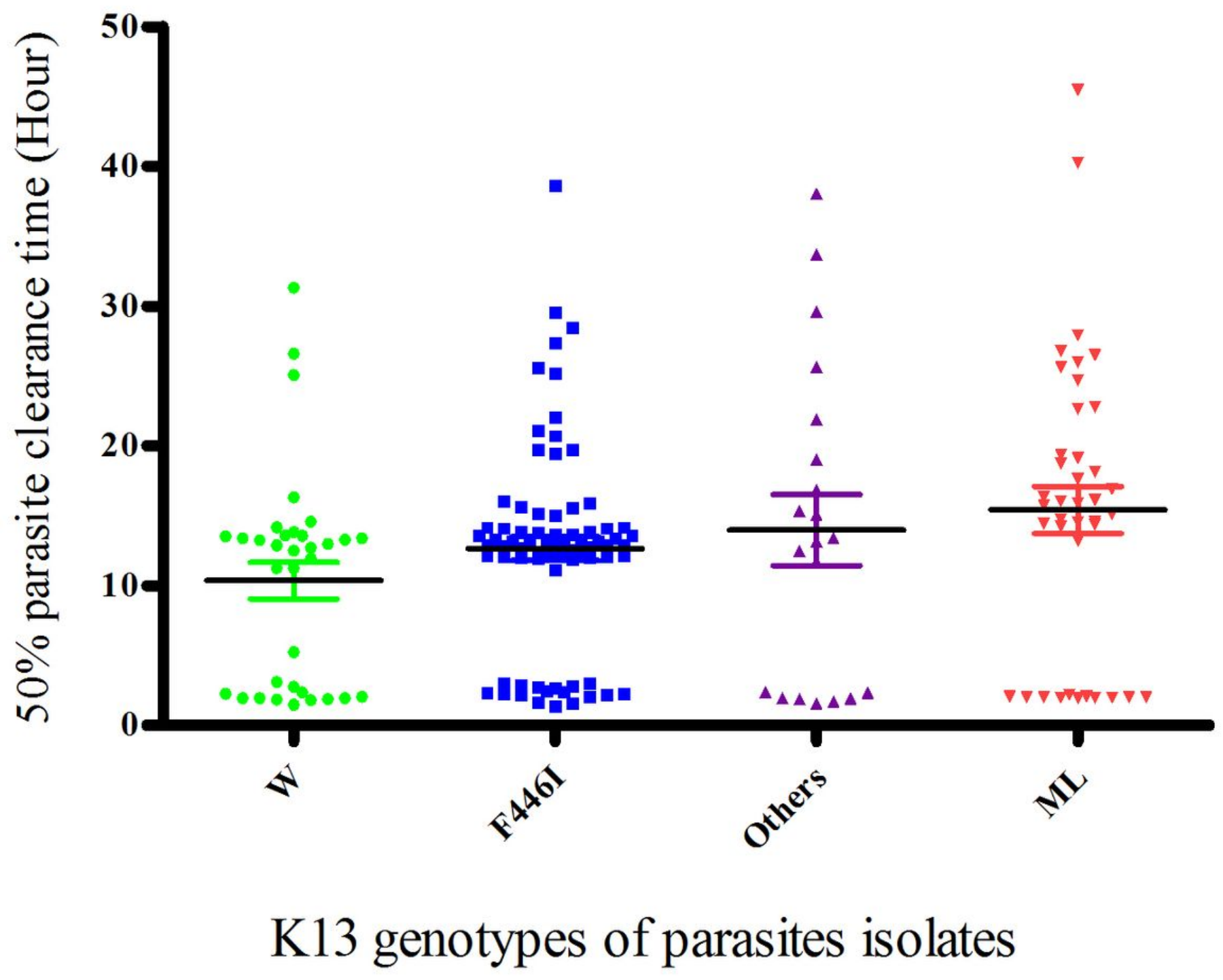

Figure 3

PCT50 variation based on $\mathrm{K} 13$ genotypes 


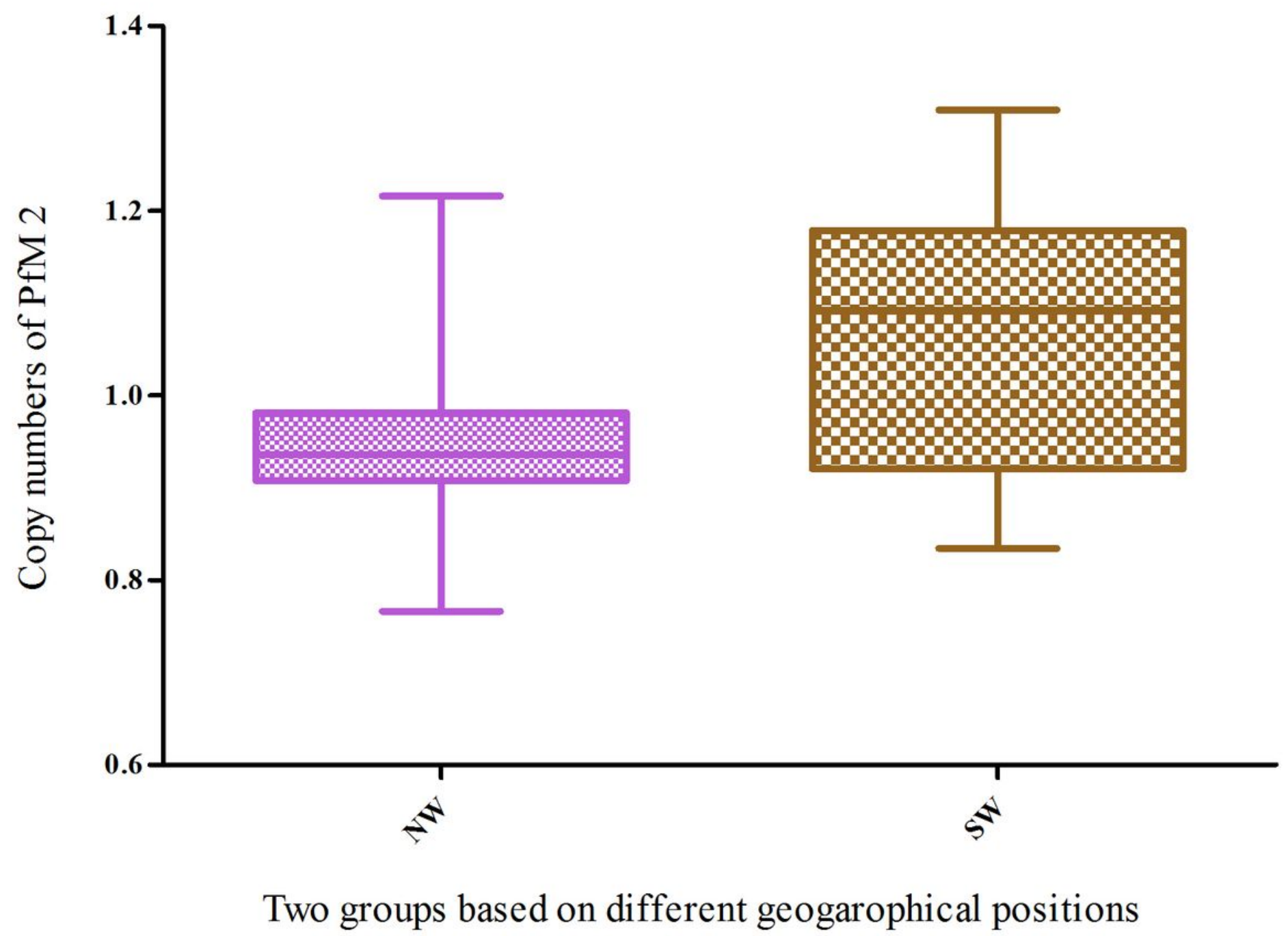

Figure 4

Copy numbers difference of PfM 2 gene based on geogaraphical positions along China-Myanmar border 


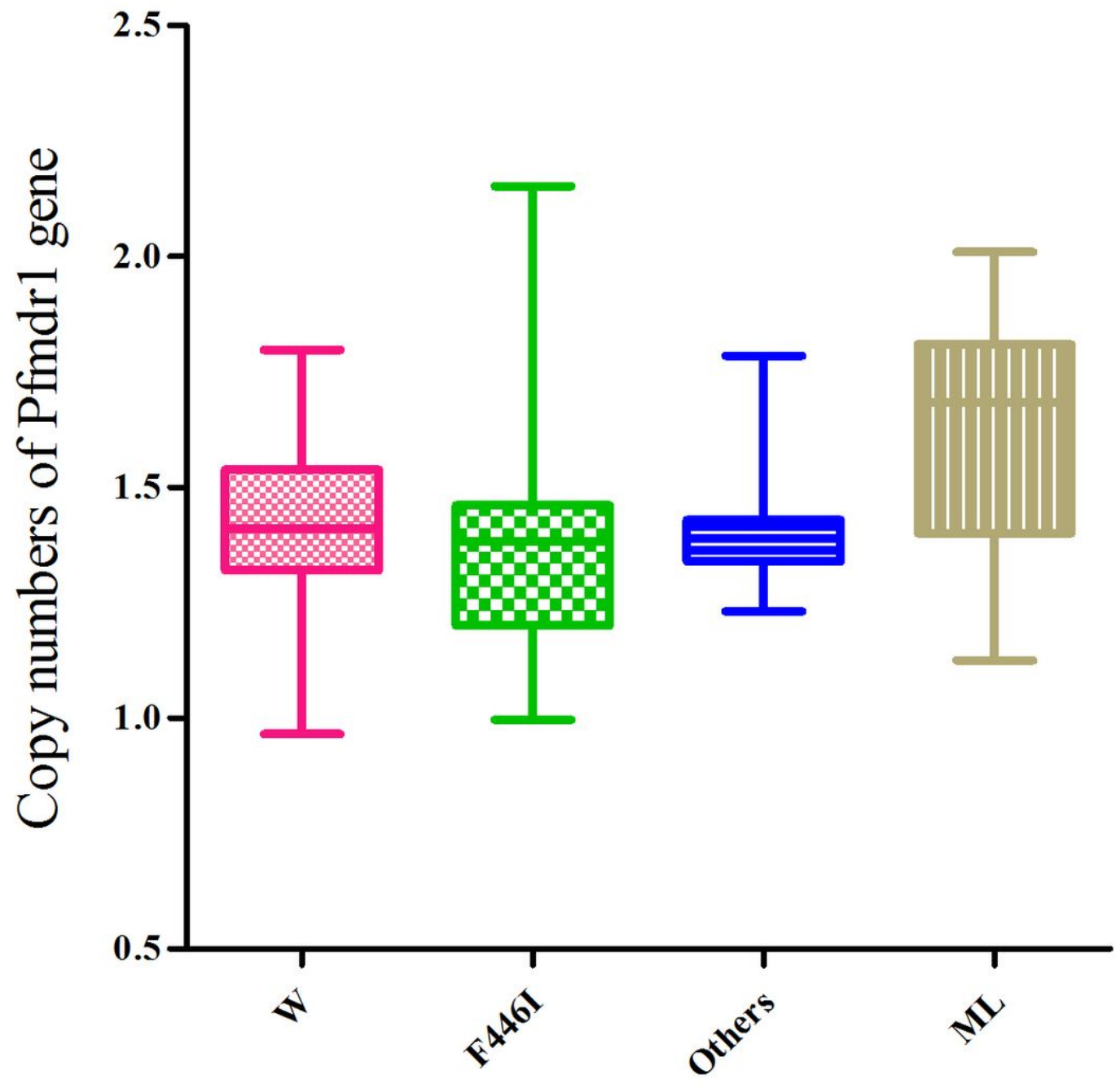

Four groups based on different K13 genotypes

Figure 5

Copy numbers difference of Pfmdr1 gene based on K13 genotypes along China-Myanmar border 


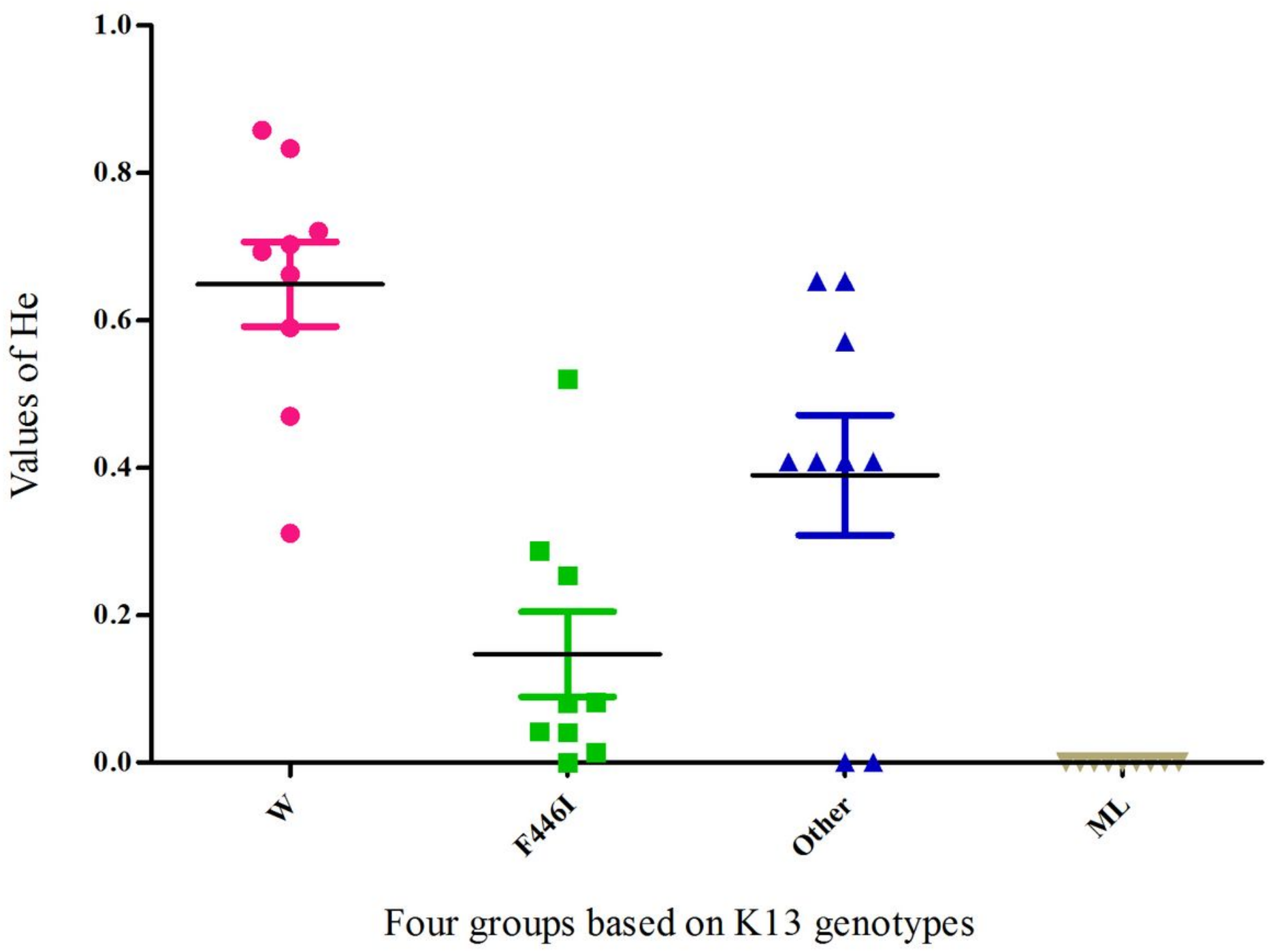

Figure 6

He variation of different groups based on K13 genotypes

\section{Supplementary Files}

This is a list of supplementary files associated with this preprint. Click to download.

- CaseswithD3positive.xlsx 